\title{
The genetics of the dystonias - a review based on the new classification of the dystonias
}

\author{
A genética das distonias - uma revisão baseada na nova classificação das distonias \\ Carlos Henrique F. Camargo 1,2, Sarah Teixeira Camargos ${ }^{3}$, Francisco Eduardo C. Cardoso ${ }^{3}$, Hélio Afonso G. Teive1
}

\begin{abstract}
The definition and classification of the dystonias was recently revisited. In the new 2013 classification, the dystonias are subdivided in terms of their etiology according to whether they are the result of pathological changes or structural damage, have acquired causes or are inherited. As hereditary dystonias are clinically and genetically heterogeneous, we sought to classify them according to the new recently defined criteria. We observed that although the new classification is still the subject of much debate and controversy, it is easy to use in a logical and objective manner with the inherited dystonias. With the discovery of new genes, however, it remains to be seen whether the new classification will continue to be effective.
\end{abstract}

Keywords: dystonia, genetics, classification, movement disorders.

\section{RESUMO}

O conceito e a classificação das distonias foram recentemente revisados. Na nova classificação de 2013, quanto à etiologia, as distonias podem ser subdividas em relação às alterações patológicas, aos danos estruturais, às causas adquiridas e à hereditariedade. Como as distonias hereditárias são clínica e geneticamente heterogêneas, buscamos classifica-las segundo os novos critérios estabelecidos recentemente. Observamos que apesar da nova classificação das distonias ainda ser objeto de discussões e controvérsias, ela pode usada com facilidade, de uma maneira lógica e objetiva, no contexto das distonias hereditárias. Com a descoberta de novos genes poderemos observar se essa classificação continuará sendo efetiva.

Palavras-chave: distonia, genética, classificação, distúrbios do movimento.

The definition of dystonia was recently revisited. Dystonia is a movement disorder characterized by sustained or intermittent muscle contractions causing abnormal, often repetitive, movements, postures, or both. Dystonic movements are typically patterned, twisting, and may be tremulous. Dystonia is often initiated or worsened by voluntary action and associated with overflow muscle activation ${ }^{1}$. If defining dystonia is difficult and controversial, classifying the various forms of dystonias is a much more complex task, primarily because the term dystonia can mean not only a disease, but also a symptom that can be part of many disorders with a wide range of causes. In an attempt to clarify the term dystonia, three "surnames" for dystonia were proposed: "symptom", "movement" and "disorder". A patient may complain of dystonia if, for example, he has a twisted neck. The patient has a dystonia symptom $\left(\right.$ dystonia $^{\mathrm{Sx}}$ ). On examination, the signs of dystonia may be confirmed. This patient then has a dystonia movement $\left(\right.$ dystonia $\left.^{\mathrm{Mov}}\right)$. Finally, dystonia as a disorder $\left(\right.$ dystonia $\left.^{\mathrm{Dx}}\right)$ requires a clinicopathologic understanding of the etiology of the disease: genetic, late-onset, post-traumatic etc ${ }^{2}$. These new concepts culminated in the replacement of the 1998 dystonia classification ${ }^{1}$. In the new 2013 classification, the dystonias are subdivided in clinical features and etiology. Clinical characteristics of dystonia necessaries for classification were age of onset, body distribution, temporal pattern, and other movement disorders/systemic diseases/neurological manifestation associated. In terms of their etiology according to whether they are the result of pathological changes or structural damage, have acquired causes or are hereditary. If there is no clearly defined etiology, the dystonia can be classified as idiopathic familial or idiopathic sporadic ${ }^{1}$.

Recent years have seen significant progress being made in our understanding of the genetics of dystonias as new loci and genes have been identified. For generalized dystonias

\footnotetext{
'Universidade Federal do Paraná, Hospital de Clínicas, Serviço de Neurologia, Unidade de Distúrbios do Movimento, Curitiba PR, Brazil; ${ }^{2}$ Universidade Estadual de Ponta Grossa, Hospital Universitário, Departamento de Medicina, Serviço de Neurologia, Ponta Grossa PR, Brazil; ${ }^{3}$ Universidade Federal de Minas Gerais, Hospital das Clínicas, Serviço de Neurologia, Unidade de Distúrbios do Movimento. Belo Horizonte MG, Brazil; Correspondence: Carlos Henrique Ferreira Camargo; Hospital Universitário - Universidade Estadual de Ponta Grossa; Al. Nabuco de Araújo, 601; Uvaranas, 84031-510 Ponta Grossa PR, Brasil; E-mail: chcamargo@uol.com.br 
the genetic mechanisms are better understood, while for focal dystonias the genes and genetic susceptibility to the disorder are not yet well identified. Hereditary dystonias $\left(\right.$ dystonia $^{\mathrm{Dx}}$ ) are clinically and genetically heterogeneous. The known genetic forms include all monogenic inheritance patterns (autosomal recessive, autosomal dominant and X-linked). Table shows the hereditary dystonias grouped according to their similarities. They are divided according to their clinical features (axis I) and etiology (axis II) in line with the new 2013 classification.

Table. The hereditary dystonias*.

\begin{tabular}{|c|c|c|c|c|c|}
\hline Clinical category & Designation & Clinical characteristics & Locus & Gene & Inheritance pattern \\
\hline \multicolumn{6}{|l|}{ Isolated dystonias } \\
\hline \multicolumn{6}{|l|}{ Persistent dystonias } \\
\hline \multirow[t]{5}{*}{$\begin{array}{l}\text { Childhood-or adolescent-onset } \\
\text { dystonias }\end{array}$} & DYT1 & $\begin{array}{l}\text { Early-onset primary } \\
\text { generalized dystonia }\end{array}$ & $9 q$ & TOR1-A or DYT1 & $A D$ \\
\hline & DYT2 & $\begin{array}{l}\text { Autosomal recessive } \\
\text { idiopathic dystonia }\end{array}$ & - & - & AR \\
\hline & DYT6 & Mixed dystonia & $8 p$ & THAP1 or DYT6 & $A D$ \\
\hline & DYT13 & $\begin{array}{c}\text { Early-onset primary } \\
\text { segmental craniocervical } \\
\text { dystonia }\end{array}$ & $1 p$ & - & $A D$ \\
\hline & DYT17 & $\begin{array}{l}\text { Idiopathic autosomal } \\
\text { recessive primary dystonia }\end{array}$ & $20 p q$ & - & AR \\
\hline \multirow[t]{5}{*}{ Adult-onset dystonias } & DYT7 & Adult-onset focal dystonia & $18 p$ & - & $A D$ \\
\hline & DYT21 & $\begin{array}{l}\text { Late-onset autosomal } \\
\text { dominant focal dystonia }\end{array}$ & $2 q$ & - & $A D$ \\
\hline & DYT23 & $\begin{array}{l}\text { Adult-onset primary cervical } \\
\text { dystonia }\end{array}$ & $9 q$ & $\mathrm{ClZ1}$ & $A D$ \\
\hline & DYT24 & $\begin{array}{l}\text { Autosomal dominant } \\
\text { craniocervical dystonia }\end{array}$ & $11 p$ & ANO3 & $A D$ \\
\hline & DYT25 & $\begin{array}{c}\text { Late-onset autosomal } \\
\text { dominant primary focal } \\
\text { dystonia }\end{array}$ & $18 p$ & GNAL & $A D$ \\
\hline \multicolumn{6}{|l|}{ Combined dystonias } \\
\hline \multicolumn{6}{|l|}{ Persistent dystonias } \\
\hline \multicolumn{6}{|l|}{ Dystonias with parkinsonism } \\
\hline \multirow[t]{3}{*}{$\begin{array}{l}\text { Without any evidence of } \\
\text { degeneration }\end{array}$} & DYT5 & $\begin{array}{c}\text { Dopa-responsive dystonia or } \\
\text { Segawa dystonia }\end{array}$ & $14 q / 1 p / 2 p$ & GCH1, TH and SPR & $A D$ and $A R$ \\
\hline & DYT12 & $\begin{array}{l}\text { Rapid-onset dystonia } \\
\text { parkinsonism }\end{array}$ & $19 q$ & ATP1A3 & $A D$ \\
\hline & DYT16 & $\begin{array}{l}\text { Adolescent-onset dystonia } \\
\text { parkinsonism }\end{array}$ & $2 p$ & PRKRA or DYT16 & AR \\
\hline With evidence of degeneration & DYT3 & $\begin{array}{l}\text { X-linked dystonia- } \\
\text { parkinsonism or lubag }\end{array}$ & $\mathrm{Xq}$ & TAF1 or DYT3 & $\mathrm{XR}$ \\
\hline \multirow[t]{2}{*}{ Dystonias with myoclonus } & DYT11 & Myoclonus-dystonia & $7 q$ & - & $A D$ \\
\hline & DYT15 & Myoclonus-dystonia & $18 p$ & SGCE & $A D$ \\
\hline Dystonias with chorea & DYT4 & $\begin{array}{c}\text { Dystonia with whispering } \\
\text { dysphonia }\end{array}$ & $19 p$ & TUBB4 & $A D$ \\
\hline \multicolumn{6}{|l|}{ Paroxysmal dystonias } \\
\hline \multirow[t]{5}{*}{ Paroxysmal dyskinesias } & DYT8 & $\begin{array}{c}\text { Paroxysmal nonkinesigenic } \\
\text { dyskinesia } 1\end{array}$ & $2 q$ & $M R-1$ & $A D$ \\
\hline & DYT20 & $\begin{array}{c}\text { Paroxysmal nonkinesigenic } \\
\text { dyskinesia } 2\end{array}$ & $2 q$ & - & $A D$ \\
\hline & DYT10 & $\begin{array}{c}\text { Paroxysmal kinesigenic } \\
\text { dyskinesia } 1\end{array}$ & $16 p q$ & PRRT2 & $A D$ \\
\hline & DYT19 & $\begin{array}{c}\text { Paroxysmal kinesigenic } \\
\text { dyskinesia } 2\end{array}$ & $16 q$ & - & $A D$ \\
\hline & DYT18 & $\begin{array}{c}\text { Exercise-induced } \\
\text { paroxysmal dyskinesia }\end{array}$ & $1 p$ & SLC2A1 or GLUT1 & $A D$ \\
\hline
\end{tabular}

*Based on Albanese et al. ${ }^{\text {and Klein }}{ }^{14}$. AD: Autosomal dominant;AR: Autosomal recessive; XR:X-linked recessive. 


\section{CHILDHOOD-ONSET AND ADOLESCENT-ONSET ISOLATED DYSTONIAS}

\section{DYT1 dystonia}

Using linkage analysis, Ozelius et al. ${ }^{3}$ mapped the locus responsible for DYT1 dystonia to the long arm of chromosome 9 (9q34) in a large family with early-onset generalized dystonia. The DYT1 (TOR1A) gene was then cloned, and a single $3 \mathrm{bp}$ (GAG) deletion was identified on chromosome 9q34 in nearly all the affected members of the families studied. The TOR1A gene is made up of five exons, and the GAG deletion is at nucleotide position 946 in exon 5. An inframe deletion results in the loss of one of a pair of glutamic acid residues (Glu-Glu) in the $\mathrm{C}$-terminal region of a protein known as torsin- $\mathrm{A}^{3}$.

With the greater access to genetic testing for dystonia patients since 1997, a wider variety of phenotypes have been associated with the mutation in TORIA. The low phenotypic penetrance (around 30\% to 40\%) indicates that there may be important environmental and/or genetic factors that could affect phenotypic expression ${ }^{4}$.

Despite the phenotypic variability associated with this dystonia, two clinical findings are observed with reasonable consistency: (1) the onset of symptoms before the age of twenty years and (2) the onset of symptoms in the limbs, mainly the legs. In most cases onset is at the end of childhood or the beginning of adolescence ${ }^{4}$. Clinical presentations indicative of focal or segmental dystonia, i.e., without spreading or generalized dystonia, should not be considered exclusion criteria for genetic testing. Based on this principle, clinical investigations into DYT1 are recommended for the following individuals: (a) patients with onset in one limb before the age of 30 years and (b) their symptomatic and nonsymptomatic relatives ${ }^{5}$.

\section{DYT2 dystonia}

The existence of DYT2, the autosomal recessive form of dystonia, is much debated. Few cases have been reported to date, and a locus associated with this dystonia has not yet been identified ${ }^{6,7,8}$. The first descriptions of cases attributed to DYT2 were in consanguineous families with various phenotypes similar to the typical DYT1 phenotype ${ }^{6,7}$. A few other reports, which did not include genetic evaluation and were only based on a recessive inheritance pattern or consanguinity, do not help clarify whether DYT2 dystonia is in fact a new disease ${ }^{8}$.

\section{DYT6 dystonia}

DYT6 dystonia has an autosomal dominant inheritance pattern. Lifetime penetrance of this disorder is estimated to be approximately $60 \%$ with no sex differences identified ${ }^{9}$. The DYT6 gene (THAP1) consists of three exons and codes for the THAP1 protein $^{10,11}$. THAP1 is a nuclear proapoptotic factor that potentiates tumor necrosis factor (TNF)- $\alpha$-induced apoptosis and serum withdrawal-induced apoptosis ${ }^{10}$. Although many of the biological functions of THAP proteins apart from their involvement in apoptotic pathways remain unknown, various findings have confirmed that they play an important role in cell proliferation ${ }^{10,11}$.

Adolescent-onset generalized dystonia followed by the segmental form is the most common presentation in most large series of DYT6 patients ${ }^{12,13,14,15}$. Other studies, in contrast, have found a predominance of patients with focal dystonia ${ }^{11,13}$. One important finding is that most patients with focal dystonia have late-onset cervical dystonia ${ }^{13}$. Since the first studies, it was observed that in patients with DYT6 dystonia, when the symptoms first appear in the limbs, they tend to predominate in the arms, unlike in DYT $1^{14,15}$.

\section{DYT13 dystonia}

DYT13 dystonia has autosomal dominant inheritance with a penetrance that has yet to be defined but is estimated at $58 \% \%^{16,17}$. In the only family studied, which was Italian, the age of onset of the symptoms varied between five and forty years (mean $15.6 \pm 12.5$ years) and was normally in the first or second decades of life. The dystonia in most cases was segmental with craniocervical and upper-limb involvement. It progressed slowly and became generalized in only $18.2 \%$ of the cases ${ }^{17}$. The phenotype of DYT13 is similar to that of DYT6 dystonia except for the lesser involvement of the larynx and legs in the former ${ }^{16}$.

\section{DYT17 dystonia}

Chouery et al. ${ }^{18}$ described a Lebanese family in which three sisters had the clinical presentation of dystonia with autosomal recessive inheritance. The initial manifestations were cervical dystonia between 14 and 19 years of age and evolved to segmental dystonia in two to three years in two patients and to generalized dystonia after nine years of the disease in the third patient. Genetic evaluation of this family mapped the locus for this novel dystonia (DYT17) to chromosome 20p11.22-q13.12.

\section{ADULT-ONSET ISOLATED DYSTONIAS}

\section{DYT7 dystonia}

The gene locus responsible for DYT7 was originally mapped to the short arm of chromosome 18 in a large German family. Seven members of the family had focal dystonia inherited in an autosomal dominant manner with incomplete penetrance, and six had late-onset cervical dystonia. Minor facial involvement, upper-limb involvement and spasmodic dysphonia were observed in the same family. There was no generalization and the disease evolved over on average nine years (two to thirty years) in the seven patients with defined focal dystonia ${ }^{19}$. 
Genetic testing in families with a phenotype similar to that of DYT7 in which there were various cases of cervical dystonia that tended to remain focal or segmental failed to find a link with the DYT7 locus ${ }^{20}$. Analysis of candidate genes in $18 \mathrm{p}$ revealed no alteration in definitely affected patients of the same German family, in a new study 15 years before. There was no disease causing copy number variant in $18 \mathrm{p}$. No potentially disease-causing mutations were detected in $18 \mathrm{p}$ by exome sequencing ${ }^{21}$. These findings suggest that there are new loci for focal dystonias that have yet to be identified.

\section{DYT21 dystonia}

DYT21 was described in a large family of non-Jewish descent from the north of Sweden with the features of dystonia with autosomal dominant inheritance. Penetrance was estimated at around $75 \%$ but can reach $90 \%^{22,23}$. Blepharospasm, cervical dystonia and upper-limb dystonia were prevalent in the affected individuals, and spasmodic dysphonia was also sometimes present ${ }^{22,23}$. In the study by Norgren et al. ${ }^{23}$, sixteen patients with dystonia were examined; six had generalized dystonia, seven multifocal dystonia, two segmental dystonia and one focal dystonia. The locus for the type of dystonia in this family was recently mapped to chromosome 2 (2q14.3-21.3). Mutational analysis was carried out on twentytwo genes in this region but failed to yield positive results ${ }^{23}$.

\section{DYT23 dystonia}

Uitti and Maraganore ${ }^{24}$ reported the first family with adultonset cervical dystonia in which monozygotic twins and various family members were affected; the disease had an autosomal dominant inheritance pattern. Even though the family was followed up over a long period, progression from the focal form to generalized dystonia was not observed in any of the members. Recently, an exonic splicing enhancer mutation [c.790A > G (p.S264G)] was identified in exon 7 of the CIZ1 gene. This mutation was found in the affected members of the family described by Uitti and Maraganore. The CIZ1 gene codes for the DNA replication factor Cipl-interacting zinc finger protein $1^{25}$.

\section{DYT24 dystonia}

Charlesworth et al. ${ }^{26}$ identified six mutations in the ANO3 gene at locus 11p14.2 in affected members of one family with autosomal dominant dystonia. The ANO3 gene encodes a $\mathrm{Ca}^{2+}$-gated chloride channel that the authors showed to be highly expressed in the striatum.

The range of age at onset varies from early childhood to the forties. The cervical region is the most common site of onset, followed by laryngeal dystonia, and then the arms; whereas the legs are never affected. In most patients, dystonia progress slowly over many years and spread to become segmental. Probably the most consistent feature in patients with DYT24 is the presence of tremor. Apart from tremor, some patients have superimposed myoclonic jerks ${ }^{27}$.

\section{DYT25 dystonia}

Fuchs et al. ${ }^{28}$ reported twenty-eight patients with dystonia in eight families, including the family initially described by Bressman et al. ${ }^{29}$ in 1994 . They confirmed that mutations in the GNAL gene were the cause of dystonia in these patients.

The family initially reported by Bressman et al. ${ }^{29}$ and the cases reported to date suggest that this dystonia, which was designated DYT25, has a phenotype that is initially predominantly cervical with a tendency to present as craniocervical dystonia with spasmodic dysphonia with or without generalization ${ }^{28}$.

\section{THE DYSTONIAS COMBINED WITH PARKINSONISM}

\section{DYT5 dystonia}

Dopa-responsive dystonia (DRD) is a rare form of dystonia, and most cases have an autosomal dominant inheritance pattern and are caused by mutations in the $G C H 1$ gene $^{30}$. Similar clinical presentations can be the result of a series of different mutations in this gene or even in another gene responsible for DRD phenotypes, or, in the case of a dystonia that is inherited in an autosomal recessive manner, the $T H$ gene $^{31}$. Some authors divide DRD into DRD-1 (or DRD-a or DYT5-a) and DRD-2 (or DRD-b or DYT5-b) according to the affected gene: the former relates to the $\mathrm{GCHI}$ gene and the latter to the $T H$ gene.

The CGH1 gene encodes the enzyme GTP cyclohydrolase I (CGH1 or GTPCHI), and the $T H$ gene encodes the enzyme tyrosine hydroxylase (TH). The $G C H 1$ gene consists of six exons. In DRD patients, various mutations have been identified in all the exons and also in the introns. Penetrance is low (approximately 30\%), but if atypical clinical presentations are taken into account, it can vary from $38 \%$ to $100 \%^{32,33}$. Penetrance is higher in females (87\% to $100 \%)$ than in males ( $38 \%$ to $55 \%$ ), and the disease is also more common in females ${ }^{34}$. Patients have defects in only one allele in this gene, i.e., they are all heterozygotes. Individuals who are homozygous for mutations in the $G C H 1$ gene do not have a clinical presentation of $\mathrm{DRD}^{34}$.

The typical DRD phenotype is characterized by dystonia concomitantly with or following parkinsonism with a worsening of symptoms during the day in $77 \%$ of cases and a dramatic response to levodopa therapy. An initial response in a few days can be observed with small doses of levodopa. The presence of chorea and dyskinesias when the levodopa dose is increased in an attempt to obtain a response is indicative of cases that are refractory to therapy ${ }^{30,35,36}$. DRD patients rarely develop motor fluctuations and dyskinesias ${ }^{36}$.

Cases of TH deficiency are rare and several mutations have been identified in some of the fourteen exons in the TH gene. The phenotypes in patients who are homozygous for mutations in the $T H$ gene and in those who are heterozygous may or may not be similar. Homozygous cases can 
present with more serious symptoms and signs, be less responsive to levodopa treatment and be more likely to develop dyskinesias ${ }^{37}$.

Tetrahydrobiopterin (BH4) deficiencies are severe neurological disorders characterized by hyperphenylalaninemia and by monoamine-neurotransmitter deficiency and caused by mutations in the genes encoding the enzymes responsible for BH4 biosynthesis and regeneration. The biosynthesis of BH4 starts from GTP via reactions catalyzed by the enzymes GTP cyclohydrolase I (GTPCH), 6-pyruvoyltetrahydropterin (PTP) synthase (PTPS), and sepiapterin reductase (SPR). Recently, autosomal recessive dystonia caused by mutations in SPR gene has been classified as DYT $5^{14}$.

\section{DYT3 dystonia}

$\mathrm{X}$-linked recessive dystonia-parkinsonism syndrome (XDP, or lubag) is a movement disorder found in male Filipino adults from the island of Panay ${ }^{38}$. It is associated with sequence changes within the TAF1/DYT3 multiple transcript system. The DYT3 gene consists of at least 43 exons that are alternatively spliced. There are alternative transcripts of exons 1-38 that encode isoforms of the TATA-box binding protein-associated factor I (TAF-1) and five exons (d1-d5) downstream to exon 38 (multiple transcript system) ${ }^{39}$.

Despite the similarities between the pathophysiological mechanisms of autosomal dominant DRD and XDP, there are major differences between the diseases, notably the fact that XDP is inherited in an X-linked recessive manner and is a heredodegenerative disorder. Only $6 \%$ of XDP patients present with parkinsonism first, while $94 \%$ present initially with focal dystonia. Dystonias of the limbs (47\%) are the most common initial presentations, particularly dystonia of the lower limbs (33\%). Cranial dystonia, such as blepharospasm, and oromandibular dystonia, such as opening and closing of the jaw, sticking out and retracting of the tongue and tremors can constitute the initial clinical presentation in $27 \%$ of cases. There is a gradual tendency for the dystonia to spread to other parts of the body, resulting in segmental, multifocal or generalized forms of the disease. After five years only $2.2 \%$ of individuals still have only focal dystonia. Among patients who have had the disease for less than two years, $84.7 \%$ have already developed the generalized form. However, there is a tendency for the clinical presentation of dystonia to revert as the disease evolves; this is more evident between the fifth and seventh years after onset of the symptoms. After ten years only around $8 \%$ of patients present with dystonia. The dystonia is gradually replaced by increasingly noticeable bradykinesia until an overall presentation of rigidity is reached. However, only minimal resting rigidity is observed, and cogwheeling is rare $^{38}$.

\section{DYT12 dystonia}

Rapid-onset dystonia-parkinsonism (RDP) is extremely rare. It has an autosomal dominant inheritance pattern and reduced penetrance. The generesponsiblefor the disease, DYT12/ATP1A3, has 23 exons and encodes the $\mathrm{Na}^{+} / \mathrm{K}^{+}$-ATPase $\alpha 3$ (ATP1A3), a catalytic subunit of the sodium pump ${ }^{40,41}$. Since the first mutations descripted by de Carvalho Aguiar et al. ${ }^{41}$, several mutations across the gene have been associated with RPD. However, the exact correlation between $A T P 1 A 3$ and the pathological mechanism of RDP remains to be elucidated ${ }^{40,41}$.

Onset of RDP typically occurs in adolescence or early adulthood, being rare over the age of forty. A striking characteristic of the disease is the sudden onset of dystonia and parkinsonism, which can develop within minutes or days of onset and are frequently triggered by a psychological stressor. RDP ceases to progress within weeks, after which there is little or no improvement except in some patients who have a slight improvement in gait. Some patients have a "second" episode one to nine years after onset ${ }^{42}$.

This dystonia typically affects the limbs and face (dysarthria and dysphagia). The dystonia and parkinsonism have a clear rostrocaudal gradient: the bulbar symptoms are more severe than the symptoms in the upper limbs, which in turn are more severe than the symptoms in the lower limbs. The first manifestations of RDP are bulbar symptoms and dystonia of the limbs accompanied by parkinsonian changes, sometimes preceded by vague symptoms. In rare cases isolated parkinsonism can precede the $\mathrm{RDP}^{42}$. Some psychiatric disorders, such as depression, personality disorders, anxiety, panic disorder and social phobia, can be found in families with $\mathrm{RDP}^{40,42}$.

Some families with alternating hemiplegia of childhood (AHC) have an autosomal dominant inheritance of the disorder, and may be caused by ATP1A3 mutations. Although the number of patients with AHC or RDP with an identified ATP1A3 mutation is rapidly growing, definitive phenotypic patterns have not been found for patients with and without mutations, and in patients with recurring ATP1A3 mutations. However, there is an interesting difference in the location in the ATP1A3 protein sequence of mutations that cause RDP or AHC. RDP mutations seem to be spread across the protein, AHC mutations are located almost exclusively in particular regions of the protein. The significance of the different mutation patterns in RDP and AHC is currently unknown, but suggests that, unlike in RDP, only specific protein disruptions result in AHC. Additionally, rarely the same aminoacid is mutated in RDP and AHC, but even in these cases the aminoacid substitution is disease-specific ${ }^{43}$.

\section{DYT16 dystonia}

Camargos et al. ${ }^{44}$ identified a dystonia with an autosomal recessive inheritance pattern in Brazilian families caused by a mutation in the PRKRA gene that encodes the interferoninducible double-stranded RNA-dependent protein kinase activator in the 2q31.3 locus, which was assigned the name DYT16 dystonia. 
The patients initially described by Camargos et al. $^{44}$, who had the c.665C $\rightarrow \mathrm{T}$ mutation, presented with an early-onset generalized disease. Onset was between the ages of two and eighteen years, and the condition manifested as a focal, predominantly limb dystonia that causes gait and writing problems and then becomes generalized ${ }^{44}$. In addition to the clinical features of dystonia, the patients described by Camargos et al. ${ }^{44}$ presented with a dystonic sardonic smile, dysarthria, dysphagia and psychiatric changes. Most of the patients had pyramidal signs (hyperreflexia and ankle clonus). In all the cases the dystonia spread to the facial, cervical or laryngeal regions, unlike another early-onset dystonia, DYT1, which starts in the limbs.

Four $(57.1 \%)$ of the patients described by Camargos et al. ${ }^{44}$ presented with parkinsonism. All had bradykinesia, and postural tremor of the limbs and freezing of gait could be observed in one patient. All the patients responded poorly or not at all to treatment with anticholinergics and levodopa.

\section{COMBINED DYSTONIAS - MYOCLONIA AND CHOREA}

\section{DYT11 dystonia}

Myoclonus-dystonia (MD), DYT11, is a rare movement disorder with an autosomal dominant inheritance pattern and variable penetrance that normally occurs in the first or second decades of life. It often improves with alcohol and is therefore sometimes known as alcohol-responsive dystonia. In most patients the myoclonus is the most prominent and incapacitating symptom ${ }^{45}$. Nygaard et al. ${ }^{46}$ localized a gene for MD, DYT11 (SGCE), to chromosome 7 (7q21-q23). SGCE has twelve exons and encodes the glycoprotein $\varepsilon$-sarcoglycan (SGCE). The typical phenotype consists of very short, abrupt myoclonic twitches that can present either in isolation or together with mild to moderate dystonia and are generally mainly in the upper part of the body ${ }^{47}$.

Dystonia is the first presentation in around $20 \%$ of patients ${ }^{48}$. The dystonia is normally mild or moderate, and cervical dystonia and writer's cramp are the most common manifestations. There may also be occasional involvement of the lower limbs, which can also be the site of onset of the disease ${ }^{47,48}$. Cases of dystonia without myoclonus can sometimes be observed, but the dystonia rarely remains the only manifestation during the course of the disease ${ }^{49}$.

Psychiatric changes such as depression, anxiety disorders, obsessive-compulsive disorder, personality disorders, drug addiction and attention deficit hyperactivity disorder have been reported in families with $\mathrm{MD}^{47}$.

\section{DYT15 dystonia}

A large family with twelve members presented with the MD phenotype, with predominantly axial myoclonia in the proximal upper limbs. Mean age of onset of symptoms was 9.6 years, and five members had dystonia. The symptoms improved with alcohol, and in half of the patients with myoclonia the disease had a relatively benign course. Inheritance was autosomal dominant with reduced penetrance. The disease was transmitted by both the father and mother ${ }^{50}$.

The same family was studied a second time, when a new locus in a $17 \mathrm{cM}$ region of chromosome 18p11 was identified as the cause of $\mathrm{MD}^{51}$. This family was clinically indistinguishable from families with mutations in the SGCE gene, suggesting that the gene products interact in the same functional biological pathways. Although there are good candidates for the gene in the critical region identified in chromosome 18, no mutations, deletions or duplications have yet been identified that could account for the disease ${ }^{51}$.

\section{DYT4 dystonia}

DYT4 dystonia was described in an Australian family with whispering dysphonia with autosomal dominant inheritance and complete penetrance ${ }^{52}$. A new Arg2Gly (c.4C > G) mutation in gene TUBB4 (tubulin $\beta$-4) was found in all the affected patients studied but not in any other family member or healthy controls ${ }^{53,54}$.

Onset in the affected individuals occurred between 13 and 37 years of age and before the age of 20 in most individuals. There was a significant variation in expression, with presentations ranging from whispering dysphonia, which the author considered a forme fruste of the disease, to complex phenotypes with choreic movements and psychiatric manifestations, which were initially diagnosed as Huntington disease or conversion disorder ${ }^{52}$. The affected members of this family had shared clinical characteristics of a thin face and body habitus. Immediately after the onset of spasmodic dysphonia, the cheeks became hollowed out, the lower part of the face tapered to the chin, the tongue became bradykinetic and exhibited poor motor patterning and the mouth remained open at rest ${ }^{55}$. Presentations that started with dysphonia evolved to focal dystonias, generalized dystonia or generalized dystonia combined with other movement disorders, such as ataxia and, primarily, chorea. Neuropsychiatric changes varied from mood swings through anxiety and psychosis to dementia. There was a report of mental retardation $^{52}$. Parkinsonism was an unusual finding. As with myoclonus-dystonia (DYT11 and DYT15), alcohol can relieve symptoms, particularly at onset ${ }^{55}$.

Concurrently, an exon 4 mutation in $T U B B 4 A$ (c.745 G > A; p.Asp249Asn) was found to cause leukoencephalopathy hypomyelination with atrophy of basal ganglia and cerebellum (H-ABC). The phenotypic spectrum of H-ABC includes dystonia, delayed psychomotor development, spasticity, ataxia, dysarthria, short stature, and microcephaly. MRI in subjects with $\mathrm{H}-\mathrm{ABC}$ shows cerebellar and striatal atrophy along with diffuse hypomyelination. Careful analysis of published DYT4 and $\mathrm{H}-\mathrm{ABC}$ phenotypes indicates the presence of significant phenotypic overlap. $\mathrm{H}-\mathrm{ABC}$ exhibits an earlier onset and more severe phenotype than DYT4. Therefore, DYT4 may be 
a "form fruste" of $\mathrm{H}-\mathrm{ABC}$. Although MRI is reportedly normal in DYT4, technical details of imaging and images have not been provided in publications related to the DYT4 pedigree. It is possible that more severely affected older individuals with the p.Arg2Gly variant do show evidence of hypomyelination and atrophy on MRI. Thus, DYT4 should not be classified as a primary dystonia ${ }^{54}$.

\section{COMBINED PAROXYSMAL DYSTONIAS}

Paroxysmal dyskinesias are rare and form a heterogeneous group that can be distinguished from other forms of dystonia by regular intermittent attacks of hyperkinetic movements without loss of consciousness ${ }^{56}$. Based on a widely accepted classification, paroxysmal dyskinesias have for many years been classified into four main groups: paroxysmal kinesigenic dyskinesias (PKDs), non-paroxysmal kinesigenic dyskinesias (NPKDs), paroxysmal exercise-induced dyskinesia (PED) and paroxysmal hypnogenic dyskinesia (PHD) ${ }^{56}$.

The PNKDs include DYT8 (PNKD-1) dystonia and DYT20 (PNKD-2) dystonia. PNKD-1 is extremely rare. The PNKD1/MR1 gene consists of 12 exons and encodes the MR-1 protein $^{57}$. PNKD-1 dystonia is characterized by attacks of resting dystonia, chorea, athetosis and ballism. Episodes can last from seconds to hours and can occur from a few times a year to several times a day. Symptoms can be brought on by alcohol or caffeine and to a lesser extent by nicotine, excitement, fatigue, anger and emotional stress. Movements, physical effort or sleep do not trigger these dyskinesias. Age at onset varies widely, and the disease can manifest for the first time during childhood, adolescence or adulthood ${ }^{56,57}$.

To date, PNKD-2 has been described in a single, large Canadian family of European origin. In all the patients dystonia was the only manifestation during an attack and always occurred in the limbs. Symptoms were not reported to be brought on by alcohol or caffeine ${ }^{56}$. Spacey et al..$^{58}$ mapped a new locus for this family very close to the MR-1 gene. Two genes in the 2q31 region, the glutamate decarboxylase gene $(G A D-1)$ and $D L X 1 / D L X 2$ have been proposed as possibly responsible for PNKD- $2^{58}$.

The PKDs include DYT10 (PKD-1) dystonia and DYT19 (PKD-2) dystonia. DYT10 dystonia, or PKD-1, is a relatively rare disease that can be familial with autosomal dominant inheritance or in some cases sporadic. Attacks normally start between six and sixteen years and are brought on by sudden, unexpected movements, hence the term kinesigenic. Men are more affected than women (ratio of men to women $=3.75: 1)^{59}$. The locus responsible for PKD-1 has been mapped to the pericentromeric region of chromosome 16, 16p11.2-q12.1 ${ }^{59}$. The condition may present with different hyperkinesias (dystonia, chorea, athetosis or ballism) in 33\% of cases, but dystonic movements on their own are most commonly reported (57\%). Unlike PNKD-1, caffeine rarely triggers attacks and alcohol never does. Episodes, which are usually unilateral, are short-lasting (seconds to minutes) and more frequent than those observed in PNKDs, occurring over 100 times a day ${ }^{59}$.

DYT19 dystonia, or PKD-2, was described in a single Indian family with autosomal dominant inheritance, slightly reduced penetrance and a clinical presentation similar to that of PKD-1. The new gene was mapped to a region close to the DYT10 locus, 16q13-q22.1, and given the name EKD2, or DYT19 ${ }^{59}$. The condition was more common among male patients (ratio of male to female $=1.8: 1$ ). Onset was during childhood between the ages of seven and thirteen years. Attacks were short-lasting (approximately two minutes), involving dystonic/choreic movements brought on by sudden movements, and occurred between one and twenty times a day.

DYT18 dystonia, or PED, is a rare disease first described in a family that presented with dystonic attacks brought on by prolonged exercise ${ }^{56,60}$. PED has an autosomal dominant inheritance pattern and slightly reduced penetrance ${ }^{60}$. Two mutations were identified in the $S L C 2 A 1$ gene in members of three families affected by PED. The $S L C 2 A 1$ gene consists of 10 exons and encodes the glucose transporter protein-1 (GLUT1), which facilitates passive diffusion of glucose across the cellular membrane ${ }^{60}$.

Clinical onset occurs during childhood and is characterized by attacks of dystonic, choreic and ballistic movements affecting primarily the upper and lower limbs. Dystonic movements are the most common. Attacks can last from a few minutes to around one hour and can affect only those limbs that are exercised. Symptoms may be accompanied by convulsive attacks, migraine, reduced cognitive function, mental retardation and aggressive, impulsive behavior ${ }^{60}$.

\section{CONCLUSION}

Although the recent revisited classification of dystonias is still the subject of much debate, it offers an easy-to-use method for classifying hereditary dystonias more logically and objectively. We look forward to the discovery of new genes, when the classification proposed here can be reviewed.

\section{References}

1. Albanese A, Bhatia K, Bressman SB, Delong MR, Fahn S, Fung VS et al. Phenomenology and classification of dystonia: a consensus update. Mov Disord. 2013;28(7):863-73. http://dx.doi.org/10.1002/mds.25475
2. Frucht SJ. The definition of dystonia: current concepts and controversies. Mov Disord. 2013;28(7):884-8. http://dx.doi.org/10.1002/mds.25529 
3. Ozelius LJ, Hewett JW, Page CE, Bressman SB, Kramer PL, Shalish $\mathrm{C}$ et al. The early-onset torsion dystonia gene (DYT1) encodes an ATP-binding protein. Nat Genet. 1997;17(1):40-8. http://dx.doi.org/10.1038/ng0997-40

4. Bressman SB, Sabatti C, Raymond D, Leon D, Klein C, Kramer PL et al. The DYT1 phenotype and guidelines for diagnostic testing. Neurology. 2000;54(9):1746-52. http://dx.doi.org/10.1212/WNL.54.9.1746

5. Albanese A, Asmus F, Bhatia KP, Elia AE, Elibol B, Filippini $G$ et al. EFNS guidelines on diagnosis and treatment of primary dystonias. Eur J Neurol. 2011;18(1):5-18. http://dx.doi.org/10.1111/j.1468-1331.2010.03042.x

6. Santangelo G. Contributo clinico alla conoscenza delle forme familiari della dysbasia lordotica progressiva (spasmo di torsione). G Psychiatr Neuropathol. 1934;52-77.

7. Giménez-Roldán S, Delgado G, Marín M, Villanuerva JA, Mateio D. Hereditary torsion dystonia in gypsies. Adv Neurol. 1988;50:73-81.

8. Zlotogora J. Autosomal recessive, DYT2-like primary torsion dystonia: a new family. Neurology. 2004;63(7):1340. http://dx.doi.org/10.1212/WNL.63.7.1340-a

9. Saunders-Pullman R, Raymond D, Senthil G, Kramer P, Ohmann E, Deligtisch A et al. Narrowing the DYT6 dystonia region and evidence for locus heterogeneity in the Amish-Mennonites. Am J Med Genet A. 2007;143A(18):2098-105. http://dx.doi.org/10.1002/ajmg.a.31887

10. Roussigne M, Cayrol C, Clouaire T, Amalric F, Girard JP. THAP1 is a nuclear proapoptotic factor that links prostate-apoptosisresponse-4 (Par-4) to PML nuclear bodies. Oncogene. 2003;22(16):2432-42. http://dx.doi.org/10.1038/sj.onc.1206271

11. Bressman SB, Raymond D, Fuchs T, Heiman GA, Ozelius LJ, Saunders-Pullman R. Mutations in THAP1 (DYT6) in early-onset dystonia: a genetic screening study. Lancet Neurol. 2009;8(5):441-6. http://dx.doi.org/10.1016/S1474-4422(09)70081-X

12. Fuchs T, Gavarini S, Saunders-Pullman R, Raymond D, Ehrlich ME, Bressman SB et al. Mutations in the THAP1 gene are responsible for DYT6 primary torsion dystonia. Nat Genet. 2009;41(3):286-8. http://dx.doi.org/10.1038/ng.304

13. Xiao J, Zhao Y, Bastian RW, Perlmutter JS, Racette BA, Tabbal SD et al. Novel THAP1 sequence variants in primary dystonia. Neurology. 2010;74(3):229-38. http://dx.doi.org/10.1212/WNL.0b013e3181ca00ca

14. Klein C. Genetics in dystonia. Parkinsonism Relat Disord. 2014;20 Suppl 1:S137-42. http://dx.doi.org/10.1016/S1353-8020(13)70033-6

15. Camargo CHF, Camargos ST, Raskin S, Cardoso FEC, Teive HAG. DYT6 in Brazil: genetic assessment and clinical characteristics of patients. Tremor Other Hyperkinet Mov (N Y). 2014;4:226. http://dx.doi.org/10.7916/D83776RC

16. Valente EM, Bentivoglio AR, Cassetta E, Dixon PH, Davis MB, Ferraris A et al. DYT13, a novel primary torsion dystonia locus, maps to chromosome 1p36.13--36.32 in an Italian family with cranial-cervical or upper limb onset. Ann Neurol. 2001;49(3):362-6. http://dx.doi.org/10.1002/ana.73

17. Bentivoglio AR, lalongo T, Contarino MF, Valente EM, Albanese A. Phenotypic characterization of DYT13 primary torsion dystonia. Mov Disord. 2004;19(2):200-6. http://dx.doi.org/10.1002/mds.10634

18. Chouery E, Kfoury J, Delague V, Jalkh N, Bejjani P, Serre JL et al. A novel locus for autosomal recessive primary torsion dystonia (DYT17) maps to 20p11.22-q13.12. Neurogenetics. 2008;9(4):287-93. http://dx.doi.org/10.1007/s10048-008-0142-4

19. Leube B, Rudnicki D, Ratzlaff T, Kessler KR, Benecke R, Auburger G. Idiopathic torsion dystonia: assignment of a gene to chromosome $18 p$ in a German family with adult onset, autosomal dominant inheritance and purely focal distribution. Hum Mol Genet. 1996;5(10):1673-7. http://dx.doi.org/10.1093/hmg/5.10.1673

20. Cassetta E, Del Grosso N, Bentivoglio AR, Valente EM, Frontali M, Albanese A. Italian family with cranial cervical dystonia: clinical and genetic study. Mov Disord. 1999;14(5):820-5. http://dx.doi. org/10.1002/1531-8257(199909)14:5<820::AID-MDS1015>3.0.CO;2-।
21. Winter P, Kamm C, Biskup S, Köhler A, Leube B, Auburger G et al. DYT7 gene locus for cervical dystonia on chromosome $18 p$ is questionable. Mov Disord. 2012;27(14):1819-21. http://dx.doi.org/10.1002/mds.25219

22. Forsgren L, Holmgren G, Almay BG, Drugge U. Autosomal dominant torsion dystonia in a Swedish family. Adv Neurol. 1988;50:83-92.

23. Norgren N, Mattson E, Forsgren L, Holmberg M. A high-penetrance form of late-onset torsion dystonia maps to a novel locus (DYT21) on chromosome 2q14.3-q21.3. Neurogenetics. 2011;12(2):137-43. http://dx.doi.org/10.1007/s10048-011-0274-9

24. Uitti RJ, Maraganore DM. Adult onset familial cervical dystonia: report of a family including monozygotic twins. Mov Disord. 1993;8(4):489-94. http://dx.doi.org/10.1002/mds.870080413

25. Xiao J, Uitti RJ, Zhao Y, Vemula SR, Perlmutter JS, Wszolek ZK et al. Mutations in $\mathrm{CIZ1}$ cause adult onset primary cervical dystonia. Ann Neurol. 2012;71(4):458-69. http://dx.doi.org/10.1002/ana.23547

26. Charlesworth G, Plagnol V, Holmström KM, Bras J, Sheerin UM, Preza E et al. Mutations in ANO3 cause dominant craniocervical dystonia: ion channel implicated in pathogenesis. Am J Hum Genet. 2012;91(6):1041-50. http://dx.doi.org/10.1016/j.ajhg.2012.10.024

27. Stamelou M, Charlesworth G, Cordivari C, Schneider SA, Kägi G, Sheerin UM et al. The phenotypic spectrum of DYT24 due to ANO3 mutations. Mov Disord. 2014;29(7):928-34. http://dx.doi.org/10.1002/mds.25802

28. Fuchs T, Saunders-Pullman R, Masuho I, Luciano MS, Raymond D, Factor $S$ et al. Mutations in GNAL cause primary torsion dystonia. Nat Genet. 2013;45(1):88-92. http://dx.doi.org/10.1038/ng.2496

29. Bressman SB, Heiman GA, Nygaard TG, Ozelius LJ, Hunt AL, Brin MF et al. A study of idiopathic torsion dystonia in a non-Jewish family: evidence for genetic heterogeneity. Neurology. 1994;44(2):283-7. http://dx.doi.org/10.1212/WNL.44.2.283

30. Segawa M. Autosomal dominant GTP cyclohydrolase I (AD GCH 1) deficiency (Segawa disease, dystonia 5; DYT 5). Chang Gung Med J. 2009;32(1):1-11.

31. Furukawa Y, Kish SJ. Dopa-responsive dystonia: recent advances and remaining issues to be addressed. Mov Disord. 1999;14(5):709-15. http://dx.doi.org/10.1002/1531-8257(199909)14:5<709::AIDMDS1001>3.0.CO;2-T

32. Nygaard TG, Trugman JM, de Yebenes JG, Fahn S. Doparesponsive dystonia: the spectrum of clinical manifestations in a large North American family. Neurology. 1990;40(1):66-9. http://dx.doi.org/10.1212/WNL.40.1.66

33. Steinberger D, Weber Y, Korinthenberg R, Deuschl G, Benecke $\mathrm{R}$, Martinius $\mathrm{J}$ et al. High penetrance and pronounced variation in expressivity of $\mathrm{GCH} 1$ mutations in five families with dopa-responsive dystonia. Ann Neurol. 1998;43(5):634-9. http://dx.doi.org/10.1002/ana.410430512

34. Furukawa Y, Lang AE, Trugman JM, Bird TD, Hunter A, Sadeh M et al. Gender-related penetrance and de novo GTP-cyclohydrolase I gene mutations in dopa-responsive dystonia. Neurology. 1998;50(4):1015-20. http://dx.doi.org/10.1212/WNL.50.4.1015

35. Kamal N, Bhat DP, Carrick E. Dopa-responsive dystonia (Segawa syndrome). Indian Pediatr. 2006;43(7):635-8.

36. Nutt JG, Nygaard TG. Response to levodopa treatment in dopa-responsive dystonia. Arch Neurol. 2001;58(6):905-10. http://dx.doi.org/10.1001/archneur.58.6.905

37. Grattan-Smith PJ, Wevers RA, Steenbergen-Spanjers GC, Fung VS, Earl J, Wilcken B. Tyrosine hydroxylase deficiency: clinical manifestations of catecholamine insufficiency in infancy. Mov Disord. 2002;17(2):354-9. http://dx.doi.org/10.1002/mds.10095

38. Lee LV, Munoz EL, Tan KT, Reyes MT. Sex linked recessive dystonia parkinsonism of Panay, Philippines (XDP). Mol Pathol. 2001;54(6):362-8. http://dx.doi.org/10.1136/mp.54.6.362 
39. Nolte D, Niemann S, Müller U. Specific sequence changes in multiple transcript system DYT3 are associated with X-linked dystonia parkinsonism. Proc Natl Acad Sci USA. 2003;100(18):10347-52. http://dx.doi.org/10.1073/pnas.1831949100

40. Pittock SJ, Joyce C, O’Keane V, Hugle B, Hardiman MO, Brett Fet al. Rapid-onset dystonia-parkinsonism: a clinical and genetic analysis of a new kindred. Neurology. 2000;55(7):991-5. http://dx.doi.org/10.1212/WNL.55.7.991

41. Aguiar PC, Sweadner KJ, Penniston JT, Zaremba J, Liu L, Caton $\mathrm{M}$ et al. Mutations in the $\mathrm{Na}+/ \mathrm{K}+-$ ATPase alpha3 gene ATP1A3 are associated with rapid-onset dystonia parkinsonism. Neuron. 2004;43(2):169-75. http://dx.doi.org/10.1016/j.neuron.2004.06.028

42. Brashear A, DeLeon D, Bressman SB, Thyagarajan D, Farlow MR, Dobyns WB. Rapid-onset dystonia-parkinsonism in a second family. Neurology. 1997;48(4):1066-9. http://dx.doi.org/10.1212/WNL.48.4.1066

43. Heinzen EL, Arzimanoglou A, Brashear A, Clapcote SJ, Gurrieri F, Goldstein DB et al. Distinct neurological disorders with ATP1A3 mutations. Lancet Neurol. 2014;13(5):503-14. http://dx.doi.org/10.1016/S1474-4422(14)70011-0

44. Camargos S, Scholz S, Simón-Sánchez J, Paisán-Ruiz C, Lewis P, Hernandez D et al. DYT16, a novel young-onset dystoniaparkinsonism disorder: identification of a segregating mutation in the stress-response protein PRKRA. Lancet Neurol. 2008;7(3):207-15. http://dx.doi.org/10.1016/S1474-4422(08)70022-X

45. Kinugawa K, Vidailhet M, Clot F, Apartis E, Grabli D, Roze E. Myoclonus-dystonia: an update. Mov Disord. 2009;24(4):479-89. http://dx.doi.org/10.1002/mds.22425

46. Nygaard TG, Raymond D, Chen C, Nishino I, Greene PE, Jennings $D$ et al. Localization of a gene for myoclonus-dystonia to chromosome 7q21-q31. Ann Neurol. 1999;46(5):794-8. http://dx.doi. org/10.1002/1531-8249(199911)46:5<794::AID-ANA19>3.0.CO;2-2

47. Roze E, Apartis E, Clot F, Dorison N, Thobois S, Guyant-Marechal L et al. Myoclonus-dystonia: clinical and electrophysiologic pattern related to SGCE mutations. Neurology. 2008;70(13):1010-6. http://dx.doi.org/10.1212/01.wnl.0000297516.98574.c0

48. Asmus F, Zimprich A, Tezenas Du Montcel S, Kabus C, Deuschl $\mathrm{G}$ et al. Myoclonus-dystonia syndrome: epsilon-sarcoglycan mutations and phenotype. Ann Neurol. 2002;52(4):489-92. http://dx.doi.org/10.1002/ana.10325

49. Doheny DO, Brin MF, Morrison CE, Smith CJ, Walker RH, Abbasi S et al. Phenotypic features of myoclonus-dystonia in three kindreds. Neurology. 2002;59(8):1187-96. http://dx.doi.org/10.1212/WNL.59.8.1187

50. Grimes DA, Bulman D, George-Hyslop PS, Lang AE. Inherited myoclonus-dystonia: evidence supporting genetic heterogeneity. Mov Disord. 2001;16(1):106-10. http://dx.doi.org/10.1002/15318257(200101)16:1<106::AID-MDS1022>3.0.CO;2-7

51. Han F, Racacho L, Lang AE, Bulman DE, Grimes DA. Refinement of the DYT15 locus in myoclonus dystonia. Mov Disord. 2007;22(6):888-92. http://dx.doi.org/10.1002/mds.21400

52. Parker N. Hereditary whispering dysphonia.J Neurol Neurosurg Psychiatry. 1985;48(3):218-24. http://dx.doi.org/10.1136/jnnp.48.3.218

53. Malpass K. Movement disorders: advancing our understanding of dystonias: genetic studies reveal TUBB4 mutation in patients with dystonia type 4. Nat Rev Neurol. 2013;9(2):59. http://dx.doi.org/10.1038/nrneurol.2013.3

54. Vemula SR, Xiao J, Bastian RW, Momčilović D, Blitzer A, LeDoux MS. Pathogenic variants in TUBB4A are not found in primary dystonia. Neurology. 2014;82(14):1227-30. http://dx.doi.org/10.1212/WNL.0000000000000294

55. Wilcox RA, Winkler S, Lohmann K, Klein C. Whispering dysphonia in an Australian family (DYT4): a clinical and genetic reappraisal. Mov Disord. 2011;26(13):2404-8. http://dx.doi.org/10.1002/mds.23866

56. Bhatia KP. The paroxysmal dyskinesias.J Neurol. 1999;246(3):149-55. http://dx.doi.org/10.1007/s004150050325

57. Rainier S, Thomas D, Tokarz D, Ming L, Bui M, Plein E et al. Myofibrillogenesis regulator 1 gene mutations cause paroxysmal dystonic choreoathetosis. Arch Neurol. 2004;61(7):1025-9. http://dx.doi.org/10.1001/archneur.61.7.1025

58. Spacey SD, Adams PJ, Lam PC, Materek LA, Stoessl AJ, Snutch TP et al. Genetic heterogeneity in paroxysmal nonkinesigenic dyskinesia. Neurology. 2006;66(10):1588-90. http://dx.doi.org/10.1212/01.wnl.0000217332.51740.7c

59. Tomita H, Nagamitsu S, Wakui K, Fukushima Y, Yamada K, Sadamatsu $M$ et al. Paroxysmal kinesigenic choreoathetosis locus maps to chromosome 16p11.2-q12.1. Am J Hum Genet. 1999;65(6):1688-97. http://dx.doi.org/10.1086/302682

60. Weber YG, Storch A, Wuttke TV, Brockmann K, Kempfle J, Maljevic $S$ et al. GLUT1 mutations are a cause of paroxysmal exertion-induced dyskinesias and induce hemolytic anemia by a cation leak. J Clin Invest. 2008;118(6):2157-68. http://dx.doi.org/10.1172/JCl34438 